\title{
Diaspora-Homeland Connection in Bharati Gautam's Vigata ra Baduli [Past and Hiccups]
}

\author{
Ramji Timalsina, $\mathrm{PhD}$ \\ Lecturer \\ Department of English, Mahendra Multiple Campus Dharan, Tribhuvan University, Nepal \\ ramjikoshi@gmail.com
}

DOI: https://doi.org/10.3126/dristikon.v11i1.39155

\begin{abstract}
This article aims to explore the way Bharati Gautam's memoir Vigata ra Baduli [Past and Hiccups] (2020) connects the writer with her homeland. Home and homeland are out of some major loci of diasporic life and the discourse. Diasporic writings deal with homeland both as a real place to return and an imaginary reality for those transnational migrants who have no chance of physical return to the place left back. To study the writer's homeland connection as expressed in the book, this study uses qualitative methodology with its interpretative approach for analysis. The theoretical input is the diasporic discourse related to home and homeland. For the diasporans, homeland is the root of their life, culture, language and in total the life they live in the hostland. The time a diaspora loses its physical, imaginary or emotional connection with the homeland, it stops being a diaspora. Thus, every diasporic writing has some kind of homeland connection. The study finds that Gautam's memoirs deal with her love and respect for the root. These feelings are expressed through her nostalgia, symbols and culture she follows in the USA. Similarly, her own and her children's critical thoughts on Nepal and Nepali socio-cultural praxis also highlight their connection with the homeland. It is hoped that this study is useful to find how Nepali Diaspora connects itself with Nepal. It may encourage the researchers to work in this field.
\end{abstract}

Keywords: Homeland, hostland, diasporic connection, memoir

\section{Introduction}

Bharati Gautam is an American Nepali diasporic writer. There are four books to her credit: Akashamathiko Shahara [City Above the Sky] (2006), Smritima Bhimu [Bhimu in Memory] (2010), Amerikama Ama [A Mother in the America] (2015) and Vigata ra Baduli [Past and Hiccups] (2020). Akashamathiko Shahara is a collection of poems that deal with the writer's experiences, thoughts and feelings of living in the America away from her homeland, Nepal. It highlights her travels and travails of being a diasporan. Her second book, Smritima Bhimu, is her memoir related to her sister-like close friend Bhimu. It mostly deals with the writer's feelings after Bhimu succumbs to untimely death. The third book, Amerikama Ama, is an autobiographical novel. It details out how the writer's personality changes from a writer and 
editor back in Nepal to a mere child-rearing mother and baby-sitter in her new land of settlement. It highlights how a diasporan is compelled to console themselves with the hope for the better future despite a very troublesome and dissatisfied life just after the transnational migration.

The award-winning book Vigata ra Baduli is a collection of memoirs. All of them deal with how the writer remembers Nepal, her parents and people, and incidents that happened in Nepal. The writer reflects on her position in both the Nepali and the American societies after she migrated to the USA and turned herself into a diasporan. Some memoirs are purely about the incidents in the USA and Sweden. Currently, she lives in the USA with her family. Her first son and only one daughter have been married and live separately; the son in Sweden and the daughter in California. Even when she describes their life in the USA and Sweden, Nepal appears in reference to social, cultural and linguistic differences. In all her books, she one way or the other shows her close connection with the homeland i.e. Nepal.

The reviewers on the book Vigata ra Baduli have also highlighted how her memoirs deal with her life in the USA and Nepal. Arun Khatri (2021) has found the book a record of the writer's pains and pleasures in the new land of settlement. He has described the presentations as the result of the writer's mentality divided between homeland and hostland. Next reviewer is Basu Shrestha (2021) who has discussed the text as the writer's conscious presentation of her situation in both the Nepali and the American societies. In the same way, Khimanand Pokhrel (2021) has observed the writer's love of Nepal and the people back there in the book. He has claimed that the writer's life in the USA, as a diasporan, has been guided by Nepali culture and consciousness in many cases. He has found gradual growth of the American consciousness in the writer.

The next reviewer is Prabha Baral (2020) who has dealt with the emotional aspect of the book. She has found herself being emotional during the reading of the book. Baral has claimed that the writings deal with Gautam's identity as a daughter, mother, sister and friend. Lila Luitel (2020) has written the review of the book with the focus on its thrust as writer's diasporicity. Luitel has highlighted some instances of nostalgia and sensitive deliberation of the incidents in the book. In the background of the book, Bharati Gautam (2020), the writer herself, has accepted that the book is a research on her own growth as a Nepali American in the USA. She has claimed that her ' $m a$ ' [self] is dominant throughout the writings in the collection. So, she expects the readers to find her condition in a diaspora.

Practically, diasporic writers are in some or the other way connect themselves with their homelands. Michael J. C. Echeruo (2001) explains the fact that the home for the diasporans "is not important only as a physical place; it is even more important as the source, root, final location for a determinable lineage" (p. 13). Gautam has also described Nepal more than a land. She treats it as the emotional location for her diasporic self. Her writings mainly deal with her 
family connection in both of the lands. So, the major concern of this study is to find out how the memoirs connect the writer with her homeland. To specify the study, this article deals with the writer's love and respect for the root, critical thought on the homeland and the use of symbols to highlight the emotional connection.

\section{Methodology}

\section{Diaspora Discourse as a Theory}

Diaspora discourse deals with the existential reality of the people who have left their homeland and have developed a community, of the people from same land of origin, in a new country. Home and homeland are two of the major ideas the diasporic discourse deals with. Robin Cohen (2008) has claimed that "Bonds of language, religion, culture and a sense of common history and perhaps a common fate impregnate a diasporic relationship". Cohen has further emphasized on the emotional connection between the diasporan's homeland and hostland as the connection "give[s] to it an affective, intimate quality that formal citizenship or even long settlement frequently lack" (p. 173). Cohen's focus, here, is on the fact that it is not only the physical and political connection, but the emotional relation is also equally important for the diasporans in regard with their connection with the homeland left back.

Moving ahead from the traditional discourse of the victim diaspora like the Jews and the Armenians, the current diaspora discourse deals even with the accumulative diaspora and their virtual connections. Cohen has claimed that "diasporas have nowadays retained their connections to home by means of virtual recreations of home and intermittent visits rather than via a return movement" (pp. 165-66). Thus, the diasporic homes and homelands are more the imaginary ones than the really physical ones. Thus, this study has used the recent discourse on the diaspora-homeland connection primarily discussed by Vijay Mishra (2007), Uma Parameshwaran (2007), Robin Cohen (2008), Michel Bruneau (2010) and Adriana Margareta Dancus (2011). All these theorists of diaspora-homeland connection focus on emotional, cultural and imaginary aspects of the homeland-hostland relation.

\section{Study Procedure}

The primary data of this qualitative research has been the memoirs collected in Bharati Gautam's book Vigata ra Baduli [Past and Hiccups] (2020). The incidents described in the memoirs and the writer's presentation of the consequent feelings she underwent during the incidents are the major corpus of the study. The support of the reviews on the book has been taken to make sure that the memoirs have diasporic themes. After that the incidents and feelings are categorized into two headings namely connection with homeland, and love and respect for the root. The categorization is followed by the analysis of the data with the use of interpretative method. The meanings of the data have been drawn with the help of how diaspora discourse plays the role in the meaning making process of the realities of the diasporic life. 
Finally, the discussion is concluded highlighting the writer's concern with her homeland, nostalgia, cultural root, symbols and worry for the homeland and people back there.

\section{Results and Discussion}

This section deals with the major thematic aspects of diaspora-homeland connection found in the book Bigata ra Baduli. Divided into two subheadings, the discussion has covered the reasons for the diasporas to get connected with the homeland, and their love and respect for the root.

\section{Connection with the Homeland}

For the diasporans, the homeland is the locus of their identity. It is their root. Bharati Gautam takes Nepal in the same sense. She writes: "nepaalalaaee mabaata jhikepachhi ma rahanna [If Nepal is taken out of me, I do not remain]" (p. 69). Nepal is the base of her identity. Even when her parents, who lived in Nepal throughout their lives, pass away, she feels: "mero mulukako upasthitinai meraa aamaabaako upasthiti rahechha [The presence of my nation is the presence of my parents]" (p. 74). For the writer, the homeland is to provide her a permanent parental protection. The way parents give identity, protection and hope for their children the homeland does all these permanently. So, when the writer sees the land of Nepal from the aeroplane in which she is returning Nepal from the USA after her ten years long stay there, she feels as if her nation has travelled to her heart. So, she finally realizes that wherever and how long one lives away from the homeland, the land cannot be a stranger to the migrant.

The writer remembers that not only her parents but also all her ancestors have been the part of the soil of Nepal. So, the soil is her parental body. She further realizes that the land always provides her culture of love, trust and faith. Then she humanizes the nature: "Chiso haawaale mero gaalaa sumasumyaayo. Maile aamaakaa haata anubhava gare. Khullaa aakaashale nihuriera angkamaala garyo. Maile baako taato shaasa mero shareeramaa anubhava gare [The cold wind caressed my cheeks. I felt my mother's hand there. The open sky bent to hug me. I experienced my father's warm breath in my body]" (p. 74). Here, home becomes "an aesthetic order" (Mishra, 2007, pp. 130). The writer's experiences remind the idea of McLeod that the concept of home in diaspora communities "can act as a valuable means of orientation by giving us a sense of our place in the world. As an idea, it stands for shelter, stability, security and comfort" (p. 210). Gautam feels her affinity with the land of Nepal.

The writer feels refreshed in Nepal. She compares herself with a tree that has dried for two decades because it could not get the water and food of its need in the hostland. But when she reaches Nepal for a short visit, she feels it gives her "jeevanako athaahaa sambhaavanaa [infinite possibility of life]" (p. 77). Her birthplace promotes the sense of energy and identity: "dhanakutaako kachide. Mero aaphno ghara. Mero aaphno parichaya. Mero nirmaanako kachchaa padaartha [Kachide from Dhankuta is my own home, my own identity, and the raw 
material of my making]" (p. 79). Here, too, McLeod sounds correct: "Migrants may well live in new places, but they can be deemed not to belong there and disqualified from thinking of the new land as their home. Instead, their home is seen to exist elsewhere, back across the border" (p. 212). Here, homeland, as Cohen claims, has "an emotional, almost reverential dimension" (2008, p. 103). It is a place of faith and respect for the diasporans.

The sense of freedom the writer feels in reaching Nepal is the result, also, of the diasporans' feeling towards the hostland and the life there. Jose Manual Mourino reports that "there is perhaps no worse prison for emigrants than the circumstances that prevent them from returning to their homeland" (in Fernandez, 2009, p. 319). So, once they are able to escape the hostland even for a short while, their "diasporic longing for the homeland" instantly "becomes both the altar and the trajectory of being" (Parameshwaran, 2007, p. 319). Even when the writer is in the USA, Nepal is always in her mind. She reports that Nepal that she had left two decades ago "comes to her dream every night [raatai nabiraai spanaamaa aauthyo]" (p. 176). So, in her arrival at Nepal, she feels: "aaphaisangako bhavanaatmaka nepaala bokera bhautika nepaala tekna aaeko [I came to land on physical Nepal carrying the emotional Nepal within me]" (p. 176). This is the first-generation migrants' feeling towards the homeland.

The second generation also has their special affinity with the place where their parents were born, grown up and which they finally left to get settled in the new land. The writer's children also want to visit Nepal whenever they get an appropriate chance. Two of her children visit Nepal as part of their international project in their university courses. In this regard, the writer comments: "Taate pani nathaalee nepaala chhodekee chhoreebhitra pani nepaala napaseko bhae sansaarakaa sabai muluka chhodera nepaalanai jaane rahara kasaree umrina sakthyo holaa ra! [The daughter who left Nepal even before she was a toddler would not have chosen Nepal leaving all the countries in the world aside if there was no Nepal inside her]" (p. 176). Observing her children's choice and love for Nepal, the writer concludes:

"nepaalasangako haamro naataa yahaa hurkiekee chhoree maatra hoina usakaa santaana ani tineeharookaa santaanasamma salkirahanechha bhanne kuraamaa malaaee patyaara laagchha [I believe that our relation with Nepal will continue not only to our children but also for many generations]" (p. 176). This shows how the homeland is a continuous phenomenon for the diasporans.

The writer also realizes that the homeland is not merely a physical entity. Moreover, it is a spiritual or emotional entity. "Dhungaamaataako nepaala jahaa chhodera aaeko bhaepani mutubhitra liera aaeko nepaala ta mutu rahesamma chhodna nasakne yathaartha merai manale thammyaauch a [My mind finds that to reach wherever we leave back the Nepal made up of the stone and soil, the Nepal I have carried within my heart cannot be away from me till my heart exists]" (p. 176). It shows that "the homeland is imbued with an expressive charge and a sentimental pathos that seem to be almost universal" (Cohen, 2008, p. 103). At the same 
time, home "becomes a mode of interpretative in-between-ness" (Radhakrishnan, 1996, p. xiii). The writer does not find her a complete Nepali or a complete American. When she thinks of being a Nepali, her hostland reminds her that she is a US citizen. Similarly, when she thinks that she is an American, she remembers that her homeland is Nepal.

Even when the writer finds the changed face of her homeland, she cannot feel to be a stranger from her heart. When the writer visits Nepal after years-long interval, she finds many changes in her homeland. She primarily talks of Kathmandu, the capital of Nepal, and Dhankuta, her birthplace. Once when she visits Dhankuta during the Dashain, she finds it as if it is a place she has never been. She has to stay in a hotel, not in any house of her relatives though the empty house where she was born and grown up is close by. She feels: "kahilyai natekeko mulukamaa pasejasto" [As if I have entered into the place I have never been]" (p. 208). She longs to see some women preparing the batti sitting on a mudha in front of their homes, some people playing the carrom board in a house yard, playing kappadi and dhyak on the road.

All these activities were usual at the town in her childhood. But now, they are not found around. Instead, she finds every small house she knows has been modified into many storey concrete buildings; some of them have housed the government offices and some others are business spots. She cannot match this game of change ["manaimana pani maile hisaaba milaauna sakekee thiena"] (p. 208). She thinks that her three-decade long spectacle may be dimmed. She blames her own perspective, not the place. She wants to find herself attached to the land despite lots of changes. Her love is seen when she returns from the place. "daado kaatunjelasamma pharkidai herdai gare [I continuously turned back to see the place as long as I could see it]" (p. 216). Thus, the diasporans find themselves connected to homeland in different forms, and keep it in their heart as a lovely root.

\section{Love and Respect for the Root}

Homeland is the root of the diaspora. Their original cultural flavor of a diaspora emanates from the land they have left back. The love and respect are so much engraved that even the negative aspects of the homeland are taken to be things of liking. When Bharati Gautam visits Nepal after her long stay in the USA, she finds the air filled with foul smell, the litter scattered everywhere, people carelessly crossing the roads and the dogs sleeping in the middle of the streets. But she does not take them to be bad; instead, she associates them with her experiences when she was in Nepal. She feels none of these practices were strange ["kehee pani paraai laagena"] (p. 72). They were her own things and practices from the past.

Her love of the past and the homeland make her feel:

Swachchha saphaa nabhaera ke bho ra? Yahaa bahane haawaa eka pataka nilnebittikai sabaibhandaa sanglo laagna thaalyo. Tyahaako chaite dhoolaale mero 
shareera chhunebittikai mero shareerale aaphantako kaakha anubhava garyo [It does not matter whether it is clean or not! Once I swallowed the air flowing here, I felt it was the cleanliest in the world. Once the Spring dust touched my body, my body experienced the lap of a relative]. (p. 73)

The writer finds every thing near and dear to her. She feels her childhood playing and youth blooming in every hill and mountain in Nepal. She feels as if she is a researcher of her own archeology and of her own existence. When she reaches the yard of the house where she was born, she feels amazed: "aghisamma shoonya dekhieko sansaara anaayaasa bhariejasto laagyo [I felt, the world that was seen empty till just a while ago was suddenly filled]" (p. 80). This is not any kind of material fulfillment, but a spiritual or emotional one.

Home is not only a physical structure; it is, instead, the place of one's liking and attachment. Parameshwaran (2007) writes: "Home is where your feet are, and may your heart be there, too!" (p. 208). Here, feet symbolize diasporic emplacement and heart refers to attachment. These images and symbols also indicate that home is both real and imagined. But, Mishra (2007) claims that "diasporas do not return to their homeland (real or imagined)" (p. 2). It means even the physical return of Bharati Gautam to Nepal is not the real return as she is there just for a short time. She is sure to return to her hostland. She is happy in meetings with the family members and relatives back there.

When she visits her place of birth with her second son, she finds everything there dear to her heart and mind. The things she used to enjoy in her childhood are not there. Even then she loves the place because the soil is the same. She stands in the tall grass and gets her photo taken. Then she remembers her childhood activities there. She is nostalgic.

Chhoraale khara ra raharako ghaaree dekhyo. Maile kaalo baardalee bhaeko aglo seto ghara dekhe. Aangana dekhe. Aamaa dekhe. Baa dekhe. Gothamaa taatnaamaa ghaansa khaairaheko singaare dekhe. ... juthelnaako thaakraamaa kaankraaharoo jhumdieko dekhe. Agenaamaa khole paakeko dekhe. Chiura, keraa, dahee, khalpee, kaanlaamaa sayapatri sabai dekhe. [The son saw the dense rough grass and pigeon pea. I saw a tall white house with a black verandah. I saw mother. I saw father. I saw the stripped coloured goat taking its grass in the shed. ... I saw the cucumbers hanging down the supports. I saw the fodder prepared in the yard. I saw beaten rice, banana, yoghurt, special cucumber pickle and marigold on the terrace edges]. (p. 216)

The writer is lost in the memory of her childhood days. Those days come to her mind being lovely.

Gautam claims that she is happy once she remembers her past. "Bigatako bhramana garer mero mana galdaina [My mind does not get tired travelling to the past]" (p. 216). She compares such a travel with a film in which a heroine is watching the film in which she herself 
is the lead actress. She finds the past like a shade that does not go out even when one switches off the light and closes the door (p. 273). Even when she finds something new in the USA and Sweden, she begins to compare it with something from her past back in Nepal. Once when she has to experience a destructive bonfire in California that destroys towns, she remembers her days back in Dhankuta when they used to work hard to save their house from the bonfire in the Spring season. At the same time, she remembers different types of fires they used to burn and enjoy in their hilly residents back in Nepal in her childhood.

The diasporans rework their life-worlds to feel safe in the hostland. Mishra (2007) claims on the basis of the Indian Diaspora's experiences in the Caribbean that "re-working the lifeworld of [homeland] ... is one way of overcoming diasporic fears of being left adrift without an anchoring point" (p. 175). In the same light, Parameshwaran (2007) highlights the diasporan's connection with their nostalgia related to homeland:

Some never grow past the phase of nostalgia. Romanticizing one's native land has a place so long as it does not paralyze one's capacity to develop new bonds within one's adopted homeland. Nostalgia as the only sustenance can become quite toxic, vitiating the living stream into a stagnant cesspool. (pp. 209-10)

The writer also does not come out of her nostalgia. Throughout the book there are innumerable instances of her love and respect to her past she spent in Nepal.

It seems that based on the past, the writer tries to plan her future. Dancus (2011) claims that "nostalgia is not only an attempt to reconstruct the past in the present by locating memory in the nostalgic objects and values, but it can also be future oriented and therefore potentially subversive" (p. 250). Gautam connects her memory with her cultural roots as well. She feels elated when she remembers her cultural activities years back in Nepal. Here, Bruneau's claims is valid: "In every diaspora, culture in the widest sense - folklore, cuisine, language, literature, cinema, music, the press as well as community life and family bonds - plays a fundamental role" (2010, p. 39). He explains the reason behind the affinity with the homeland culture in the diaspora: "Through migration, diaspora members have lost their material relationship to the territory of origin, but they can still preserve their cultural or spiritual relationship through memory ... re-rooting in the host country" (2010, p. 49). Gautam has used her love for the past in the same sense.

She tries to recreate Nepali culture in her American home. She has put a conch in the cupboard. A conch is a cultural symbol of Hindu prayers and religious practices. It is used in both the sacred ceremonies conducted during the life and also in the funeral procession. There is a saffron colour Shreemadbhagavat text in her American cupboard. Shreemadbhagavat is taken to be the most practical religious book that is recited and listened by the Hindu people continuously for seven days. It is one of the puranas [legends] that have both the religious and 
historical significance. Moreover, this purana is the practical summary of the total Hindu philosophy. To preserve the text of Shreemadbhagavat is to respect and preserve the Hindu culture the writer was grown with in Nepal. This is the love and respect not only to the immediate root, but also love and respect to cultural, historical and philosophical roots.

She has preserved the photos they took in her childhood and youth in Nepal. They treasure the memories of both her good and bad days back then and there. Though she feels very sad seeing her dead junior sister's photo in her secret album, she sometimes realizes that this photo is able to keep her connected with the sister she loved and cared so much. She has also kept the cassettes of the Nepali hymns her maternal uncle and aunt have sung together. It connects her not only to the demised relatives, but also to their love of culture, tradition and art. All these are done due to love and respect to the root.

\section{Conclusion}

Bharati Gautam's Bigata ra Baduli [Past and Hiccups] is an example of how the diasporas get connected with the homeland. The writer presents many instances of facts and emotions that show how the diasporas take the homeland as the source of identity, cultural root, love and respect. The memoirs in the book present the diasporan's nostalgia that celebrates the homeland as the land of inspiration. Even the negative aspects of the homeland are celebrated as the dear ones. Everything including the physical set up of the homeland and its culture works as a symbol for the diasporas. Even the parents, relatives, books, cultural objects and the birthplace have symbolic significance for them. The memoirs show that in whatever form and wherever they live, the homeland is a place of great significance for the diasporas. Diasporas exist only up to the point they maintain some kind of connection with their homelands.

\section{References}

Bajgain, K. (2020). Prakashakiya [Publisher's note]. In B. Gautam, Vigata ra baduli [Past and hiccups] (pp. 7-8). Samakalin Literary Academy.

Baral, P. (2021). Smritiko premila dharohar: Vigata ra baduli [Lovely heritage of memory: Past and hiccups]. Banita, 60, 37-39.

Bruneau, M. (2010), Diasporas, transnational spaces and communities. In R. Bauböck and T. Faist (Eds.). Diaspora and transnationalism: Concepts, theories and methods (pp. 3549). Amsterdam University Press.

Cohen, R. (2008). Global diasporas: An introduction. 2nd ed. Routledge.

Dancus, A. M. (2011). Diasporic feelings and displaced nostalgia: A case study Scandinavian Studies 83(2), 247-266. http://www.jstor.org/stable/23075459 
Echeruo, M. J. C. (2001). An African diaspora: The ontological project. In I. Okpewho, C. B. Davies, and A. A. Mazrui (Eds.) The African diaspora: African origins and new world identities (pp. 3-18). Indiana University Press.

Fernandez, J. (Ed.). (2009). Diasporas: Critical and interdisciplinary perspectives. InterDisciplinary Press.

Gautam, B. (2020). Vigata ra baduli [Past and hiccups]. Samakalin Literary Academy.

Huyssen, A. (2003). Diaspora and nation: Migration into other pasts. New German Critique, 88, 147-164. http://www.jstor.org/stable/3211163

Khatri, A. (2021, March). Vigata ra baduli adhyayan garda [Studying past and hiccups]. Rachana, 169, 100-101.

Luitel, L. (2020). Vigatako baduli lagda [Experiencing hiccups of the past]. In B. Gautam, Vigata ra baduli [Past and hiccups] (pp. 9-16). Samakalin Literary Academy.

McLeod, J. (2010). Beginning postcolonialism. Viva Books.

Mishra, V. (2007). The literature of the Indian diaspora: Theorizing the diasporic imaginary. Routledge.

Parameshwaran, U. (2007). Writing the diaspora: Essays on culture and identity. Rawat Publications.

Pokhrel, K. (2021, May 29). Vigata ra baduliko mohamaa phaseki Bharati Gautam [Bharati Gautam: Involved in the love of past and hiccups.]. email.

Radhakrishnan, R. (1996). Diasporic mediations: Between home and location. University of Minnesota Press.

Shrestha, B. (2021, Feb.-Apr.). Vigata ra badulima dubulki lagauda [Delving into Past and hiccups]. Shivapuri Sandesh, 27, 99, 36-40. 